\title{
A REVIEW OF WINE TOURISM DESTINATION IMAGE STUDIES FROM 2001 TO 2020
}

\author{
Gvantsa SEKHNIASHVILI* \\ Hungarian University of Agriculture and Life Sciences, Doctoral School \\ of Economic and Regional Sciences, Hungary, e-mail: gvantsasekhniashvili @yahoo.com
}

\begin{abstract}
Citation: Sekhniashvili, G. (2021). A REVIEW OF WINE TOURISM DESTINATION IMAGE STUDIES FROM 2001 TO 2020. GeoJournal of Tourism and Geosites, 37(3), 757-767. https://doi.org/10.30892/gtg.37304-706
\end{abstract}

\begin{abstract}
As wine tourism destination image research attracts more attention lately, it is necessary to synthesize the literature and monitor its development. By analyzing the accumulated knowledge in the field, our study aims to form a practical guide based on which future research can avoid duplication and focus on the detected gaps The paper uses literature review methodology of 21 studies published between 2001 and 2020. Sample articles were coded and analyzed by different variables. The results explain some of the features of the field such as common measurement methods, study subjects and objects, samples and their size, destination types, scales, topics, and so forth. It summarizes strengths and weaknesses as well as future research possibilities. Based on the results, it is proposed to diversify the subjects of the study, also, to improve the measurement techniques of wine tourism destination image and focus on projected image which lacks the attention.
\end{abstract}

Key words: destination image, literature review, wine tourism, winescape, destination image measurement, wine region imagery, perceived image

\section{INTRODUCTION}

Research about destination image (DI) concept in tourism was initiated in the early 1970s (Echtner and Ritchie, 1991; Stepchenkova and Mills, 2010) and after almost a half-century-long popularity, now it occupies an important role in tourism-related studies. Researchers' extended interest in DI is linked to its importance for individual's behavior regarding travel decision-making (Chon, 1990; Gallarza et al., 2002; Stepchenkova and Mills, 2010; Tasci et al., 2007). The results of DI studies are often used by destination marketing organizations (DMO) as they realize that "in order to be successfully promoted in the targeted markets, a destination must be favourably differentiated from its competition, or positively positioned, in the minds of the consumers" (Echtner and Ritchie, 1991: 37). Exploring and monitoring DI enables DMOs to better manage perceived or projected DIs in target travel markets (Stepchenkova and Mills, 2010). The significance of tourism destination imagery for wine regions has been recognized by several authors (Bruwer et al., 2016; Bruwer and Gross, 2017; Scorrano et al., 2018), who note that wine tourism destination image (WTDI) research is limited. In his study about WTDI Williams (2001b) notices that wine regions manage to be differentiated from other kinds of destinations, but "they may fail to distinguish how one wine area is distinguished from the next" (Williams, 2001b: 53).

He suggests that for the successful positioning of wine tourism destinations, the projected images should match the wine tourists' preferences (Williams, 2001b). Bruwer et al. (2016) consider that wine tourism product and experience need a research perspective adapted to their nature and differentiated from the generic DI studies. Given this framework, the purpose of our paper is to summarize and synthesize the literature related to WTDI with the goals of understanding its current state of knowledge, providing a practical guide for fellow researchers and encourage future studies. Current paper acknowledges the recommendation by Tasci et al. (2007): "frequent and critical monitoring of the image construct through literature reviews is required to shed light on the necessary adjustments of methodological rigor and focus of inquiry" (Tasci et al., 2007: 195). In DI field, several authors (Chon, 1990; Echtner and Ritchie, 1991; Gallarza et al., 2002; Nghiêm-Phú, 2014; Pike, 2002; Stepchenkova and Mills, 2010; Tasci et al., 2007) have reviewed previous literature, and these studies have been used as a guide for our research design process. In this research, similarly to some of the preceding studies (Chon, 1990; Nghiêm-Phú, 2014; Tasci et al., 2007), the literature review methodology was applied. As Grant and Booth (2009) explain, "the literature review method seeks to identify what has been accomplished previously, allowing for consolidation, for building on previous work, for summation, for avoiding duplication and for identifying omissions or gaps" (Grant and Booth, 2009: 97), however, it does not usually involve comprehensive data. To overcome this methodological weakness, we tried to include all the research papers about WTDI, which met the criteria discussed below in the Data collection section. Therefore, the research questions of this review are:

1. What is the existing knowledge about WTDI?

2. What are the characteristics of WTDI studies between 2001 and 2020 ?

\section{LITERATURE REVIEW}

Previous reviews of DI research

Chon (1990) was one of the first authors who reviewed 23 most frequently cited studies about DI in tourism and

\footnotetext{
* Corresponding author
} 
classified them under six topics: "(1) the influence of a destination image in traveler satisfaction; (2) the role of a destination image in traveler buying behavior, i.e. his travel related decision making; (3) the change of destination image; (4) the formation and modification of a destination image through cross-national and cross-cultural contacts; (5) destination image assessment and measures; and (6) the role of a destination image and tourism development" (Chon, 1990: 3). Based on this review, he suggested a conceptual model of a relation between DI and traveler's behavior (Chon, 1990).

One year later, Echtner and Ritchie (1991) reviewed 15 papers about DI in tourism to assess its conceptualization and measurement. This paper found a dominance of quantitative methods over qualitative ones, meaning a lack of research focused on holistic and unique components of DI (Echtner and Ritchie, 1991). Echtner and Ritchie (1991) also provided a list of DI attributes summarized from the reviewed quantitative studies.

Around a decade later, Pike (2002) has examined 142 papers about DI published from 1973 to 2000. This study discussed some characteristics of DI research, such as measurement approaches, data analysis methods, focus of studies etc.

Gallarza et al. (2002) provided a conceptual model of tourism DI as well as a classification of the applied methodologies and a summary of utilized DI attributes. This paper is based on an overview of 65 studies published during the period of 1971-1999, which were grouped in seven different topics such as "conceptualization and dimensions", "destination image formation process (static and dynamic)", "assessment and measurement of destination image", "influence of distance on destination image", "destination image change over time", "active and passive role of residents in image study", and "destination image management policies (positioning, promotion, etc.)" (Gallarza et al., 2002: 58).

Tasci et al. (2007) carried out a critical review of DI articles sourced from renowned journals of tourism and other related fields. This study concluded that conceptualization and operationalization constructs had not yet been systematized, and it highlighted some of the methodological issues regardless of the fact that many researchers took into consideration “evolutionary advances" (Tasci et al., 2007: 217) provided by Echtner and Ritchie (1991). Stepchenkova and Mills' (2010) intention was to identify "current and emerging trends" (Stepchenkova and Mills, 2010: 582) in DI research with a qualitative meta-analysis of 152 articles published between January 2000 - October 2007. This article discusses ten trends in DI studies that assist an efficient development of future research. One of the latest reviews of such scale and importance as the former studies was conducted by Binh Nghiêm-Phú (2014), who identified characteristics of 177 DI papers published between 20082012. He provided aspects of previous studies and recommendations for the development of the literature body.

\section{Destination image}

DI definition has often been unclear or even omitted (Echtner and Ritchie, 1991), which lead Echtner and Ritchie (1991) to design a conceptual framework of DI involving its attribute-based and holistic perception, functional and psychological characteristics, and common and unique features. This structure requires the use of a combination of qualitative and quantitative methodologies for proper measurement of DI (Echtner and Ritchie, 1991). In other words, structured methods should be dealing with functional and psychological attributes, while unstructured methods such as open-ended questions should be exploring the holistic perceptions and unique component of the DI (Echtner and Ritchie, 1991). After more than a decade from Echtner and Ritchie's $(1991,1993)$ framework proposal, the studies still were not using a uniform definition and measurement of DI (Gallarza et al., 2002; Tasci et al., 2007). Therefore, Tasci et al. (2007) synthesized the components of the DI and proposed a system, which has a cognitive knowledge of destination's common and unique attributes and the affective feelings about them at its core; based on these aspects, a holistic image is formed and assists the individual in travel decisionmaking. In this system "factors cannot be comprehended in isolation; therefore, they should be studied in an integrated manner. Thus, a DI is an interactive system of thoughts, opinions, feelings, visualizations, and intentions toward a destination" (Tasci et al., 2007: 200). As a result of an overview of DI constructs, Stepchenkova and Mills (2010) also concede with cognitive, emotional or affective, and conative or behavioral elements of DI, as well as its overall impression.

\section{Wine tourism destination image}

WTDI papers (Madeira et al., 2019; Scherrer et al., 2009; Sottini et al., 2019) often study wine-producing regions as a type of destination in interest. In other words, from travel perspective, wine region and wine tourism destination terms could probably be used interchangeably. One more term which intends to describe a similar concept is winescape. Wine region is a place where wine is produced and with appropriate facilities it can become a travel destination (Dávid and Bujdosó, 2007; Nemethy et al., 2016). Wine tourism destination could be a wine region or any other place where wine tourism activities take place. Quintal et al. (2015) refer to winescape as a "grape wine environment" (Quintal et al., 2015: 597), Johnson and Bruwer (2007) define it as a connection of "vineyards; wineries and other physical structures; wines; natural landscape and setting; people; and heritage, town(s) and buildings and their architecture and artefacts within, and more" (Johnson and Bruwer, 2007: 277). Winescape is studied from macro (wine region) and micro (winery) approaches (Quintal et al., 2015). Hall et al. (2000) interpret winescape as "the attributes of a grape wine region" (Hall et al., 2000: 4). Researchers who assess WTDI (Bruwer and Gross, 2017; Scorrano et al., 2018; Williams, 2001a) use all these three concepts. Therefore, WTDI studies beliefs, perceptions, thoughts, feelings, ideas, expectations, and knowledge about a wine tourism destination, in other words, wine region or winescape, that is projected by destination management bodies and perceived by wine tourists. Thus, it is important for a proper research of WTDI to establish a framework suitable for wine tourism product (Bruwer et al., 2016).

\section{METHODOLOGY}

\section{Data collection}

This study is a review of the literature about WTDI. The data collection and data analysis had several steps, which is 
summarized in Figure 1. Firstly, we decided which database to use for the paper search. We were considering choosing between Google Scholar, a free search engine, and Scopus and Web of Science (WoS), which we had access to. All these databases have their advantages and disadvantages. The main reason why we decided not to use Google Scholar in our search was that its content is not limited only to scholarly materials, and its algorithm does not let users filter the data based on its publication type, i.e. article, student hand-book, editorial notes, theses and so forth (Noruzi, 2005). On the other hand Scopus and WoS offer "scholarly and professional literature" (Jacso, 2005: 1540), and unlike Google Scholar, their contents are comprehensive and disclosed (Jacso, 2005). We collected data from Scopus and WoS.

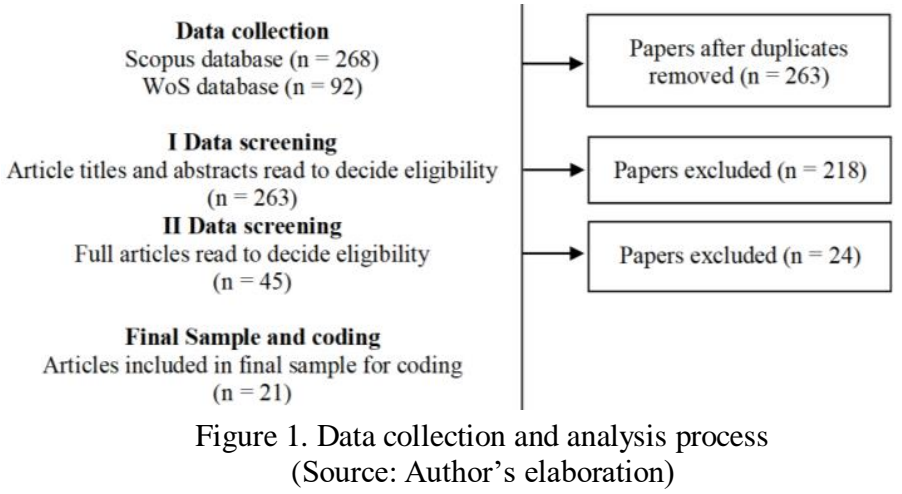

Table 1. Keywords used to search articles in Scopus and WoS databases and corresponding number of findings (Source: Author's elaboration)

\begin{tabular}{|c|c|c|c|}
\hline $\begin{array}{c}\text { Keywords } \\
\text { used for } \\
\text { search }\end{array}$ & $\begin{array}{c}\text { Keywords } \\
\text { used to filter } \\
\text { the results }\end{array}$ & $\begin{array}{c}\text { Number of } \\
\text { articles found } \\
\text { in the Scopus } \\
\text { database }\end{array}$ & $\begin{array}{c}\text { Number of } \\
\text { articles found } \\
\text { in the WoS } \\
\text { database }\end{array}$ \\
\hline $\begin{array}{c}\text { "destination } \\
\text { image" }\end{array}$ & "wine" & 155 & 33 \\
\hline "winescape" & & 28 & 33 \\
\hline "brand equity" & "wine tourism" & 54 & 8 \\
\hline "brand image" & "wine tourism" & 31 & 18 \\
\hline Total & & 268 & 92 \\
\hline
\end{tabular}

Secondly, we selected the following keywords "destination image", "wine", "winescape", "brand equity", "brand image", "wine tourism" and their combinations to gather the results. Table 1 explains the keyword search process in a more detailed way. Then, we picked only academic peer-reviewed journal articles for our study, which was done by filtering the results according to the document type. The number of papers identified on Scopus and WoS databases was 268 and 92, respectively. Finally, we have removed the duplicates and read the titles and abstracts of 263 remaining works to decide which papers to include in our primary sample. This search procedure was repeated twice, in November 2020, and in January 2021 to ensure that all the necessary documents were found. The primary sample incorporated 45 articles. Afterwards, we thoroughly read and coded the papers in Microsoft Excel. At this point, the final sample was decided too. We excluded 24 articles, as some were not in English, others were preprints, and the rest was not focused on DI and wine tourism. As our goal was to collect the papers exhaustively, we did not limit our sample to any period, which means that the time span when the sample articles were published was known only after the final sample was identified. Table 2 displays 21 articles covered in our research. They study WTDI and are published during $2001-2020$.

\section{Data analysis}

The analysis of the literature was made using a coding system with the variables adopted from the previous DI reviews (Chon, 1990; Echtner and Ritchie, 1991; Gallarza et al., 2002; Nghiêm-Phú, 2014; Pike, 2002; Stepchenkova and Mills, 2010; Tasci et al., 2007). We reviewed each full-text paper to find out about the variables such as journal title and ranking, authors and publication year. We also coded papers according to the topic, focus on perceived versus projected image, countries for study, wine-producing region, and type and number of destinations in interest. Other variables were study sample and its size, DI measurement methods (data collection modes), and attributes. Table 2 shows the analyzed characteristics for each article. All the articles in the sample are empirical. However, some papers provide a more in-depth review of concepts and literature than others; they could be considered a combination of conceptual and empirical studies, but we did not classify them according to this variable, as it was beyond our study goals.

Table 2. Summary of characteristics of WTDI studies between 2001 and 2020 (Source: Author's elaboration)

\begin{tabular}{|c|l|l|c|l|}
\hline N & \multicolumn{1}{|c|}{ Author, year } & \multicolumn{1}{|c|}{ Country } & $\begin{array}{c}\text { The number } \\
\text { of destinations } \\
\text { of interest }\end{array}$ & \multicolumn{1}{|}{ Topics } \\
\hline 1 & (Williams, 2001a) & Country & NA & Projected image \\
\hline 2 & (Bruwer and Lesschaeve, 2012) & NA & 1 & Winescape framework, focus on WTDI \\
\hline 3 & (Gómez and Molina, 2012) & Canada & 4 & Destination image as a part of the brand equity construct \\
\hline 4 & (Sampaio, 2012) & Spain & 1 & Links between destination image and other concepts \\
\hline 5 & (Pratt and Sparks, 2014) & Portugal & NA & Links between destination image and other concepts \\
\hline 6 & (Bruwer et al., 2016) & NA & 1 & Winescape framework, focus on WTDI \\
\hline 7 & (Bruwer and Joy, 2017) & Australia & 1 & Winescape framework, focus on WTDI \\
\hline 8 & (Bruwer et al., 2017) & Canada & 1 & Winescape framework, focus on WTDI \\
\hline 9 & (Bruwer and Gross, 2017) & USA & 1 & Winescape framework, focus on WTDI \\
\hline 10 & (Scorrano et al., 2018) & Australia & NA & Winescape framework, focus on WTDI \\
\hline 11 & (Bruwer et al., 2018) & NA & 1 & Links between destination image and other concepts \\
\hline 12 & (Scherrer et al., 2009) & Australia & 1 & Winescape framework, focus on WTDI \\
\hline 13 & (Gómez et al., 2013) & Spain & 2 & Destination image as a part of the brand equity construct \\
\hline 14 & (Gómez, Lopez, et al., 2015) & Spain & 5 & Destination image as a part of the brand equity construct \\
\hline
\end{tabular}




\begin{tabular}{|l|l|l|c|l|}
\hline 15 & (Madeira et al., 2019) & Spain & 1 & Links between destination image and other concepts \\
\hline 16 & (Wu and Liang, 2020) & Portugal & 1 & Links between destination image and other concepts \\
\hline 17 & (Bauman et al., 2020) & China & 1 & $\begin{array}{l}\text { "Destination image acts as the conceptual lens with which this } \\
\text { research aims to explore tourists' perceptions of a destination } \\
\text { impacted by natural disaster" (Bauman et al., 2020: 2479) }\end{array}$ \\
\hline 18 & (Bruwer and Alant, 2009) & USA & 1 & Winescape framework, focus on WTDI \\
\hline 19 & (Sottini et al., 2019) & South Africa & 1 & Analyzing only one attribute of winescape: an image of rural landscape \\
\hline 20 & (Gómez, González-Díaz, et al., 2015) & Italy & 5 & Destination image as a part of the brand equity construct \\
\hline 21 & (Bruwer and Rueger-Muck, 2019) & Spain & 1 & Winescape framework, focus on WTDI \\
\hline
\end{tabular}

Summary of characteristics of WTDI studies between 2001 and 2020 (continued) (Source: Author's elaboration)

\begin{tabular}{|c|l|c|l|}
\hline $\mathbf{N}$ & Sample & Sample size & Technique for generation of attributes \\
\hline 1 & $\begin{array}{l}\text { Wine tourism destination visual images published between 1991 and } \\
\text { 1999 in The Wine Spectator }\end{array}$ & 50 & Literature review \\
\hline 2 & Winery visitors (first-time and repeat visitors) & 996 & NA \\
\hline 3 & Winery managers & 173 & Literature review \\
\hline 4 & Winery visitors & 303 & Literature review \\
\hline 5 & Wine consumers & 696 & $\begin{array}{l}\text { Literature review and qualitative research } \\
\text { (qualitative research details not discussed) }\end{array}$ \\
\hline 6 & $\begin{array}{l}\text { Winery visitors (in-state and out-of-state visitors; wine-tourist and non- } \\
\text { wine-tourist; first-time and repeat visitors) }\end{array}$ & NA \\
\hline 7 & $\begin{array}{l}\text { Winery visitors (wine tourism specialists and generalists; first-time and } \\
\text { repeat visitors) }\end{array}$ & 510 & NA \\
\hline 8 & Winery visitors (first-time and repeat visitors; in-state and out-state visitors) & 334 & NA \\
\hline 9 & Winery visitors (who consumed wine at least once in the last 3 months) & 407 (pick-any list, survey), & Literature review \\
\hline 10 & $\begin{array}{l}\text { Wine tourists and wine-bloggers of Web 2.0. globally (visitors and } \\
\text { non-visitors) }\end{array}$ & 366 & NA \\
\hline 11 & Winery visitors (wine learners, dining enthusiasts, wine buyers) & 671 & Unclear. Previous literature? \\
\hline 12 & Winery owners or managers and winemakers & 23 & NA \\
\hline 13 & Winery visitors & 232 & Literature review \\
\hline 14 & Winery managers and winery visitors & 219 winery managers, 598 & Literature review \\
\hline 15 & Winery visitors & 314 & Literature review \\
\hline 16 & Potential tourists from China & 378 & Literature review \\
\hline 17 & Wine tourists (who had visited California within the prior two years) & 600 & Not discussed \\
\hline 18 & Winery visitors (first-time and repeat visitors) & NA \\
\hline 19 & Flickr photos (filtered with coordinates, keywords etc.) & 9228 & NA \\
\hline 20 & Winery visitors & 598 & Literature review \\
\hline 21 & $\begin{array}{l}\text { Winery visitors (Millennials, Gen-Xers, Boomers Plus; wine tourism } \\
\text { Specialists and generalists) }\end{array}$ & 513 & NA \\
\hline
\end{tabular}

Summary of characteristics of WTDI studies between 2001 and 2020 (continued) (Source: Author's elaboration)

\begin{tabular}{|c|c|c|c|}
\hline & Data collection modes & Scales used in qualitative studies & Method \\
\hline$\frac{\mathbf{N}}{1}$ & Visual imagery on promotional material (the wine spectator magazine) & $\begin{array}{l}\text { A visual imagery was coded using a scale ranging from } \\
\mathrm{O}=\text { =no presence; } 1=\text { a little emphasis; } 2=\text { moderate } \\
\text { emphasis; } 3=\text { considerable emphasis. }\end{array}$ & Quantitative \\
\hline 2 & Free elicitation/open-ended question (purpose-designed questionnaire) & NA & Qualitative \\
\hline 3 & Face-to-face questionnaire survey & Multi-item measurement scales, a 7-point Likert scale & Quantitative \\
\hline 4 & Questionnaire & 5-point Likert scale & Quantitative \\
\hline 5 & Email and postal mail survey & Likert scale & Quantitative \\
\hline 6 & Free elicitation/open-ended question (purpose-designed questionnaire) & NA & Qualitative \\
\hline 7 & Free elicitation/open-ended question (purpose-designed questionnaire) & NA & Qualitative \\
\hline 8 & Free elicitation/open-ended question (purpose-designed questionnaire) & NA & Qualitative \\
\hline 9 & Self-administered survey, free elicitation & 10-point Likert-type scale, a pick-any list & Combined \\
\hline 10 & $\begin{array}{l}\text { Free elicitation/open-ended questions (Digital questionnaire } \\
\text { posted on Facebook and Twitter pages) }\end{array}$ & NA & Qualitative \\
\hline 11 & Self-administered purpose-designed questionnaire & Not discussed & Quantitative \\
\hline 12 & Semi-structured interviews & NA & Qualitative \\
\hline 13 & Questionnaire & Multi-item measurement scales, 7-point Likert scale & Quantitative \\
\hline 14 & Face-to-face questionnaire survey & 7-point Likert scale & Quantitative \\
\hline 15 & Face-to-face questionnaire survey & 5-point Likert scale & Quantitative \\
\hline 16 & Paper-and-pencil questionnaire & Not discussed & Quantitative \\
\hline 17 & $\begin{array}{l}\text { Questionnaire with close-ended and open-ended questions } \\
\text { (Amazon M-Turk, an online crowdsourcing marketplace) }\end{array}$ & Multiple categorical, Likert-type & Combined \\
\hline 18 & $\begin{array}{l}\text { Self-administered highly structured questionnaire (capturing } \\
\text { both quantitative and qualitative data) }\end{array}$ & NA & Qualitative \\
\hline 19 & $\begin{array}{l}\text { Photos (related to winescape concept) and their geographical } \\
\text { coordinates from Flickr platform }\end{array}$ & NA & Qualitative \\
\hline 20 & Face-to-face questionnaire survey & Multi-item measurement scales, 7-point Likert scale & Quantitative \\
\hline 21 & $\begin{array}{l}\text { Free elicitation (purpose-designed highly structured self- } \\
\text { administered questionnaire) }\end{array}$ & NA & Qualitative \\
\hline
\end{tabular}




\section{RESULTS AND DISCUSSION}

\section{Journals}

Collected articles were published mainly in tourism and hospitality journals (17 articles), but also in wine ( 2 articles), business $(1$ article) and general social science $(1$ article) category journals. The list of the journals and number of publications about WTDI, representing our study sample, are presented in Table 3. The list also integrates journal ranking according to the 2019 Scimago Journal and Country Rank (SCImago (n.d.), n.d.). The papers were either published in Q1(12 papers) or Q2-ranked (nine papers) journals (SCImago (n.d.), n.d.), indicating high quality of research in this area.

Table 3. List of journals where the sample articles were published (Source: Author's elaboration)

\begin{tabular}{|l|c|c|c|c|c|}
\hline \multicolumn{1}{|c|}{ Tourism and hospitality journals } & $\begin{array}{c}\text { Number of } \\
\text { articles }\end{array}$ & $\begin{array}{c}\text { SJR } \\
\text { rank }\end{array}$ & \multicolumn{1}{|c|}{ Non-tourism journals } & $\begin{array}{c}\text { Number } \\
\text { of articles }\end{array}$ & $\begin{array}{c}\text { SJR } \\
\text { rank }\end{array}$ \\
\hline International Journal of Tourism Research & 3 & Q1 & EuroMed Journal of Business & 1 & Q1 \\
\hline Current Issues in Tourism & 3 & Q1 & Quality and Quantity & 1 & Q2 \\
\hline Tourism Recreation Research & 2 & Q2 & Wine Economics and Policy & 1 & Q1 \\
\hline Journal of Travel and Tourism Marketing & 2 & Q1 & $\begin{array}{l}\text { International Journal of Wine } \\
\text { Business Research }\end{array}$ & 1 & Q2 \\
\hline Tourism Analysis & 2 & Q2 & & \\
\hline Tourism Economics & 1 & Q2 & & \\
\hline Tourism Management & 1 & Q1 & & \\
\hline Anatolia An International Journal of Tourism and Hospitality Research & 1 & Q2 & & \\
\hline Journal of Destination Marketing and Management & 1 & Q1 & & & \\
\hline Tourism and Hospitality Research & 1 & Q2 & & \\
\hline Total & & & & \\
\hline
\end{tabular}

\section{Publication year}

The earliest study from our sample was published in 2001. Figure 2 displays the amount and share of the publications from 2001 to 2020. The first half of our study period (2001-2010) was not as active as the second half (2011-2020). Only $15 \%$ of the papers were published in the first decade. The period between 2001 and 2020 was divided into four to better analyze the increase in the popularity of the topic. Comparing each five-year period, the number of publications rise gradually, which confirms a slow but steady growth of interest in the WTDI topic.

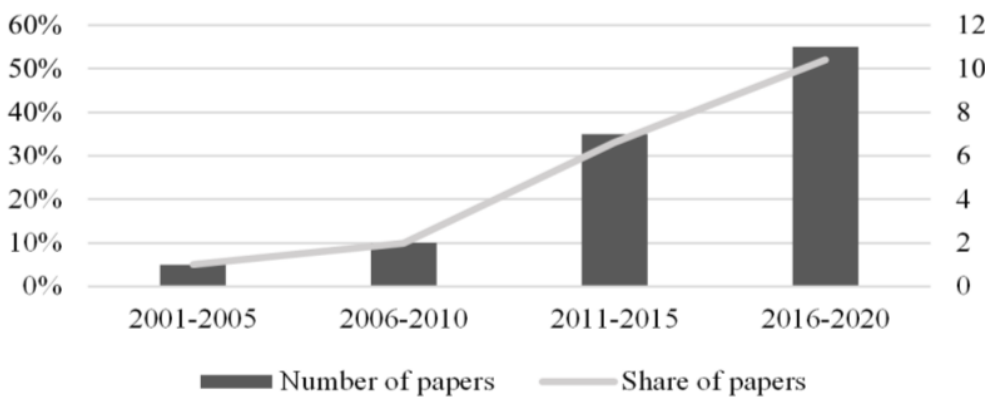

Figure 2. The amount and share of publications between 2001 and 2020 (Source: Author's elaboration)
Table 4. Average number of authors per paper between 2001-2020 (Source: Author's elaboration)

\begin{tabular}{|c|c|}
\hline Period & $\begin{array}{c}\text { Average number of } \\
\text { authors per paper }\end{array}$ \\
\hline $2001-2005$ & 1 \\
\hline $2006-2010$ & 2.5 \\
\hline $2011-2015$ & 2.3 \\
\hline $2016-2020$ & 3 \\
\hline
\end{tabular}

\section{Authors}

We have counted the average number of authors per paper for four 5-years periods between 2001-2020. As Table 4 shows, the average number of authors between 2001-2005 was one, it has increased to 2.5 in the next five years. Between 2011-2015 the number has slightly dropped but noticeably rose to three since 2016. The increase of collaboration and coauthorship means growth in knowledge sharing, which positively affects WTDI research quality (Gómez et al., 2019). Most of the authors (88\%) have only published one article. The rest $12 \%$ of authors have published more than one study. The most active authors in the field of WTDI are Johan Bruwer (8 papers), Mar Gómez (4 papers), Arturo Molina (4 papers), Marlene A. Pratt (2 papers) and Michael J. Gross (2 papers).

\section{Topic}

We have categorized papers based on the studied topics. Six topics emerged. Most of the studies (43\%) concentrate on measuring single WTDI or winescape perceptions. Five articles (24\%) research links between DI and other concepts. For instance, one of the studies (Sampaio, 2012) examines a conceptual model of wine involvement, DI and tourist satisfaction, another (Pratt and Sparks, 2014) researches relationship between self-congruity, attitude toward wine tourism and DI. Four papers (20\%) were grouped under the topic of a DI as a part of the brand equity construct. For example, one of the paper (Gómez, González-Díaz, et al., 2015) studies DI, designation of origin (DO) brand image and brand equity construct. The remaining three papers belong to single-paper topic groups. One of them (Williams, 2001a) researches the projected image using visual imagery on promotional material. In a study by Bauman et al. (2020) "destination image acts as the conceptual lens with which this research aims to explore tourists' perceptions of a destination impacted by natural disaster" (Bauman et al., 2020: 2479). And Sottini et al. (2019) analyze only one attribute of the wine region which is an image of a rural landscape. 
Projected and perceived image studies

We classified articles based on the focus on the projected or perceived image. DI is studied from two perspectives: projected and perceived images (Kwek and Lee, 2008). Perceived images are formed by the information that tourists have in mind (Andreu et al., 2000). Binh Nghiêm-Phú (2014) has collected the definitions of perceived image and summarized that "perceived destination image can be regarded as the knowledge, impressions, prejudices, imaginations, emotional thoughts, beliefs, ideas, conceptions, attitudes, benefits, values, expectations, and interpretations that an individual holds about a destination. Destination image is formed over time from a variety of information sources and consists of both the cognitive/reasoned and affective/emotional aspects" (Nghiêm-Phú, 2014: 40). Projected image derives from different channels such as destination management bodies and tour operators (Andreu et al., 2000).

"Specialists in marketing and branding proved that a touristic destination becomes more attractive according to the way it is presented and less of the touristic attractions" (Ilieş et al., 2008: 146). Both projected and perceived images are crucial for tourist destination competitiveness (Ahmed, 1991; Andreu et al., 2000). Even though the importance of projected image has been recognized for more than two decades (Chan and Zhang, 2018), perceived image studies dominate the research field (Nghiêm-Phú, 2014). All the papers from our sample except for one research perceived image. WTDI studies are in accordance with the DI literature review by Binh Nghiêm-Phú (2014), which also concludes that projected image studies are overlooked. Williams (2001a) is the author of the only study which examined projected image from our sample, this study explored characteristics of wine tourism destination positioning with the help of visual images published in The Wine Spectator magazine between 1991 and 1999, these images were classified according to the list of attributes collected from previous literature. The findings showed that wine destination imagery changed its orientation from wine production to aesthetics and experience represented with leisure and touristic activities (Williams, 2001a). Other papers which explore perceived image (Bruwer et al., 2016; Bruwer and Joy, 2017; Bruwer and Lesschaeve, 2012) frequently try to determine winescape characteristics and attributes by surveying winery visitors' perceptions. Some studies research perceived image by wine consumers (Pratt and Sparks, 2014) or winery managers (Gómez et al., 2015; Gómez and Molina, 2012; Scherrer et al., 2009).

\section{Region / destination}

Aleixandre et al. (2016) explain that wine-producing countries belong either to "Old World" or "New World"; "Old World" refers to the ancient wine-producing regions which are in Europe and the Mediterranean; Italy, Austria, Hungary, Spain, Greece, France, Portugal, Romania are some of them; examples of "New World" regions are located in USA, Australia, Canada, New Zealand, Argentina, Chile, South Africa etc. In our research, we aimed to gather information about four variables related to regions/destinations. The papers were classified based on the countries for study, wine-producing regions ("Old World" /" New World"), number and type of destinations of interest. The results show that Spain (24\% of papers) and Australia (19\% of papers) are the most popular countries for study, followed by Canada, Portugal, and USA (10\% of papers each); China, South Africa and Italy being in focus only once (5\% of papers each); a country for the study was not applicable in three articles (14\%). In other words, these results mean that "New World" (10 papers) is a slightly more popular study area than "Old World" (eight papers).

Figure 3 presents a relationship of a publication year and a region for study. "Old World" was more popular in the first half of the 2011-2020 period, while a number of studies focused on "New World" stroke in the second half.

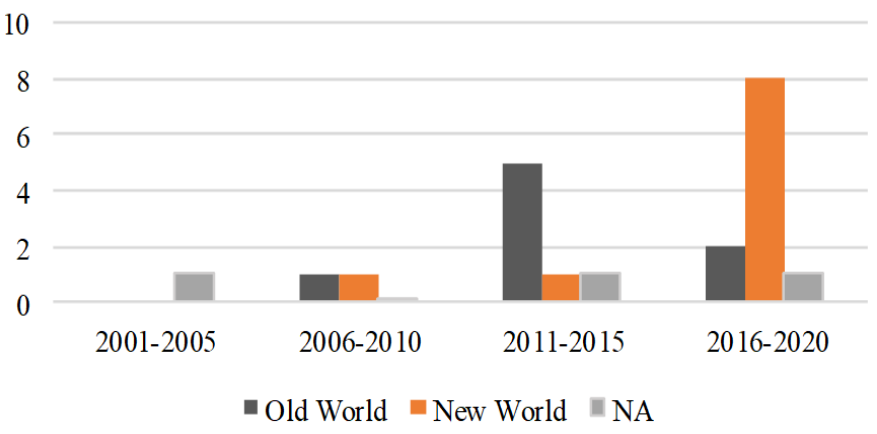

Figure 3. Study area of the papers (Source: Author's elaboration)
Table 5. Study samples (Source: Author's elaboration)

\begin{tabular}{|c|c|}
\hline Sample & $\begin{array}{c}\text { Number of } \\
\text { articles studied } \\
\text { this sample }\end{array}$ \\
\hline Winery visitors & 13 \\
\hline Winery managers, owners, and winemakers & 3 \\
\hline Visual images & 2 \\
\hline Potential tourist & 1 \\
\hline $\begin{array}{c}\text { Wine tourists and wine-bloggers of Web } \\
\text { 2.0. globally (visitors and non-visitors) }\end{array}$ & 1 \\
\hline $\begin{array}{c}\text { Wine tourists (who had visited the } \\
\text { destination within the prior two years) }\end{array}$ & 1 \\
\hline Wine consumers & 1 \\
\hline
\end{tabular}

Most articles (67\%) concentrate only on one destination, two articles (10\%) analyze five destinations; the variable of the number of destinations was not applicable in three papers; the rest of the articles examine two (5\%) and four (5\%) destinations. These findings demonstrate that WTDI studies are rather concerned with measuring and assessing one destination's image than comparing or referring them with competitors. This finding is in parallel with a review of Pike (2002), where over $50 \%$ of articles studied the perceptions of only one destination. The reason could be its early stage of development, where researchers yet try to deal with conceptualization and determination of the most appropriate measurement methods for WTDI. Previous DI reviews found that the most common destination types were countries, cities and states (Gallarza et al., 2002; Pike, 2002). As our sample of papers is chosen from wine tourism literature, it is no surprise that the type of destination is more specific. All the articles uniformly focus on wine-producing regions. 


\section{Study sample}

When researchers know the purpose of the study, who or what will be the subject, and how the study will be operationalized, they need to think about the sample size. In his review, Pike (2002) has observed that most of the articles about DI used subject category of "visitors at destinations" (Pike, 2002: 542), followed by "consumers at their place of residence", "travel trade/experts", "student samples", "Destination Marketing Organisation (DMO) staff", and "local residents" (Pike, 2002: 542). While Gallarza et al. (2002) detected four samples: residents, tourists, visitors and unspecified. Our research has gathered information about a sample and its size. As presented in Table 5, winery visitors are the most popular sample studied 13 times, followed by the group of winery managers, owners and winemakers referred in three papers. Visual images were studied twice, and the rest of the samples were only investigated in one research. Winery visitors sample could be considered as comparable with the Pike's (2002) "visitors at destinations" (Pike, 2002: 542), and in both cases it is the most common subject type. In some of the papers which targeted winery visitors, the samples were further specified and are displayed in Table 6. Five articles simply studied winery visitors, another five researched firsttime and repeat visitors, two studies explored perceptions of in-state and out-of-state visitors, two papers surveyed wine tourism specialists and generalists; other less frequently researched subjects were Millennials, Gen-Xers, Boomers Plus; wine-tourist and non-wine-tourist; and wine learners, dining enthusiasts and wine buyers. Compared to Pike (2002) and Gallarza et al.'s (2002) reviews, in WTDI papers, the important subject types such as DMOs, travel trade representatives, and residents are not explored yet. While the samples studied in papers were homogenous during 2001-2015, new subjects started to appear in recent years. Scorrano et al. (2018) used a sample of wine tourists and wine-bloggers online (visitors and non-visitors), Wu and Liang (2020) surveyed potential tourists from China, Bauman et al. (2020) questioned wine tourists (who had visited the destination within the prior two years), and Sottini et al. (2019) selected a subject of visual images from Flickr platform. As DI is a complex concept that can refer to imagery projected by DMOs or impressions of residents, tourists, and travel businesses, it is crucial to diversify study subjects that would positively affect research development.

It is difficult to select the appropriate size of a sample both in quantitative and qualitative researches, as it is conditioned by different aspects such as study purpose, size of a population, permissible sampling error and so forth (Israel, 1992). Nowadays, in quantitative research, authors use tools for defining sample size easily based on some factors such as "power, effect size (ES), significance level, and in the case of longitudinal or repeatedmeasures research, the potential attrition (dropout) rate" (Duffy, 2006: 9).

Table 6. Further classification of the study sample of winery visitors (Source: Author's elaboration)

\begin{tabular}{|l|c|}
\hline \multicolumn{1}{|c|}{ Sample } & $\begin{array}{c}\text { Number of articles } \\
\text { studied this sample }\end{array}$ \\
\hline Winery visitors & 5 \\
\hline Winery visitors (first-time and repeat visitors) & 5 \\
\hline Winery visitors (in-state and out-of-state visitors) & 2 \\
\hline Winery visitors (wine tourism specialists and generalists) & 2 \\
\hline Winery visitors (Millennials, Gen-Xers, Boomers Plus) & 1 \\
\hline Winery visitors (wine-tourist and non-wine-tourist) & 1 \\
\hline Winery visitors (wine learners, dining enthusiasts, wine buyers) & 1 \\
\hline
\end{tabular}

In qualitative research, academics often use saturation to decide the sample size. Saturation is "the point where the main ideas and variations relevant to the formulation of a theory have been identified" (Weller et al., 2018: 2). However, researches often lack the explanation of how saturation has been estimated (Malterud et al., 2016). On the other hand, "since the goal of research based on qualitative data is not necessarily to collect all or most ideas and themes but to collect the most important ideas and themes, salience may provide a better guide to sample size adequacy than saturation" (Weller et al., 2018: 2).

Sample size in qualitative studies might have lower and upper limits (Boddy, 2016). Sometimes a single case study with one research participant can provide significant insight and can be considered as an acceptable size; regarding the upper limits, too large sample sizes frequently will need to be justified; for instance, more than 30 in-depths interviews or 12 focus groups (Boddy, 2016). To sum up, in quantitative and qualitative studies, an appropriateness of the sample size depends on the context and research design of an individual paper (Boddy, 2016).

In our papers, we coded the number of subjects used when measuring a WTDI. In a few studies, sample size was different when assessing various elements of a construct or framework. In such cases, we only coded the sample size applied in the DI measurement process. The Sample size varied from 23, when the study subjects were winery owners or managers and winemakers (Scherrer et al., 2009), to 9228, where the subject was Flickr photos (Sottini et al., 2019). We tried to find out the range of study sample sizes, excluding the lowest and highest extremes which would probably distort the range. Sample size of quantitative studies ranged between 173-696 except a paper by Williams (2001a) applying a content analysis of visual imagery and picked 50 images from a population of 90 . The sample size of qualitative studies was between 265-996, except for two articles. One of them interviewing 23 winery owners or managers and winemakers and another analyzing 9228 visual images. A sample size of study with combined methodologies varied between 395-600.

\section{Destination image measurement methods (data collection modes)}

Echtner and Ritchie (1991) proposed combining qualitative and quantitative methods to enable studying all aspects of DI during its measurement process. It means using both an attribute-based and a holistic approach. The attribute-based approach captures respondents perceptions about destination in interest commonly using Likert or semantic differential scales (Echtner and Ritchie, 1991; Gallarza et al., 2002; Stepchenkova and Mills, 2010), while the holistic method intends to explore functional holistic, psychological holistic and unique components of DI and generally involves asking openended questions similar to the ones used by Echtner and Ritchie (1993): 
1. What images or characteristics come to mind when you think of $\mathrm{XXX}$ as a vacation destination? (functional holistic component)

2. How would you describe the atmosphere or mood that you would expect to experience while visiting XXX? (psychological holistic component)

3. Please list any distinctive or unique tourist attractions that you can think of in XXX. (unique component)" (Echtner and Ritchie, 1993, Development of Open-Ended Questions section).

By combining these two techniques, "those parts of destination image that can be broken down into attributes are captured, as are the total, holistic impressions" (Jenkins, 1999: 5).

Jenkins (1999) overviews the two major methods of DI measurement. The advantages of structured methods are: the ease of administration, coding, and statistical data analysis, as well as possibility to compare destinations; the disadvantages include incapability of measuring holistic image, limiting respondents to evaluate DI through the list of specified attributes, in this method some attributes can be missed and cause the incomplete results (Jenkins, 1999). On the other hand, unstructured methods allow researcher to study holistic compounds of DI, interviewer bias is reduced, and the important aspects of an image are less likely to be missed; but unstructured methods have some disadvantages too: variable level of details provided by interviewees, statistical analysis and comparison between destinations is limited (Jenkins, 1999). To sum up, for the most reliable results, an application of combined methods is highly recommended.

Jenkins (1999) proposes to assess DI with a two-phase model which is widely used in social sciences, it would start with "sound qualitative research that provides the constructs relevant to the market being studied" (Jenkins, 1999: 13), and continue with a quantitative stage where "the research needs to take into account the level of importance of these constructs to different individuals and groups" (Jenkins, 1999: 13). For instance, the qualitative phase could include uncovering the attributes by content analysis, free elicitation, triad elicitation or photo-elicitation, and then quantitative "measurement could involve asking the tourists to rate certain destinations according to the attributes distilled earlier" (Jenkins, 1999: 11). Jenkins (1999) notes that "past research into destination image has often neglected the initial qualitative stage and has favoured structured methods containing categories often based on the researcher's opinions or those found in the literature without testing to see if these are the most relevant to the group being studied" (Jenkins, 1999: 13). Echtner and Ritchie (1991) also recommend rigorous research with consumers (the target audience) in the initial phase of research design to build a complete attribute list for measuring DI as "it is difficult to design a valid and complete set of destination image attributes without such input" (Echtner and Ritchie, 1991: 45), however past researches mainly used literature reviews, brochures or travel expert opinions for designing attribute lists (Echtner and Ritchie, 1991). In our sample of 21 papers, we could not find the research which closely followed the above-mentioned guidelines regarding DI measurement. Ten papers (48\%) used quantitative methods to measure DI, nine papers (43\%) used qualitative methods, and two papers (10\%) used combined methods when collecting main data for analysis.

Among qualitative studies, the data was collected mainly by free elicitation/open-ended question (6 papers). Still none of the open-ended questions, except for the one used by Scorrano et al. (2018), tried to explore or distinguish psychological holistic and unique components of the image. It is understandable as these studies were focused on designing a general scale for future use. Scorrano et al. (2018) used three different questions to find about all the elements of DI formulated by Echtner and Ritchie (1991, 1993). Two combined methodology studies also used free elicitation/open-ended question but with similar drawbacks as the qualitative studies. In Table 7 we display the openended questions that were used in articles that applied qualitative and combined data collection modes. Most of the questions are alike, probably because Johan Bruwer is the co-author of six of them. These papers are a significant contribution to the unstructured or holistic methodology that has long been overlooked in tourism DI studies (Bruwer et al., 2016). However, the WTDI lacks research that would involve both qualitative and quantitative methods to fill in the gaps left by either data collection modes during the DI measurement process. In addition, the qualitative data gathered by most open-ended questions in Table 7 neglects psychological holistic and unique components of the tourism DI.

Table 7. Open-ended questions used in papers with qualitative and combined data collection modes (Source: Author's elaboration)

\begin{tabular}{|l|c|}
\hline \multicolumn{1}{|c|}{ Open-ended question } & Data collection mode \\
\hline $\begin{array}{l}\text { 1. “What would you (in your own words) say are the Niagara Wine Region's main characteristics or features?" } \\
\text { (Bruwer and Lesschaeve, 2012: 618) }\end{array}$ & Qualitative \\
\hline $\begin{array}{l}\text { 2. "What would you (in your own words) say are the Adelaide Hills Wine Region's main characteristics or } \\
\text { features?" (Bruwer et al., 2016: 181) }\end{array}$ & Qualitative \\
\hline $\begin{array}{l}\text { 3. "What would you (in your own words) say are the Okanagan Valley Wine Region's main characteristics or } \\
\text { features?" (Bruwer and Joy, 2017: 8) }\end{array}$ & Qualitative \\
\hline $\begin{array}{l}\text { 4. "What would you (in your own words) say are the Finger Lakes Wine Region's main characteristics or } \\
\text { features?" (Bruwer et al., 2017: 169) }\end{array}$ & Qualitative \\
\hline $\begin{array}{l}\text { 5. "The first layer of analysis technique is primarily qualitative in nature, and asks participants to state in free-text } \\
\text { format what they consider to be the study region's main characteristics or features" (Bruwer and Gross, 2017:501). }\end{array}$ & Combined \\
\hline $\begin{array}{l}\text { 6. Wine tourists were asked to provide answers to the following questions based on the top-of-mind approach: } \\
\text { "(1) Images and characteristics: elements that come to the mind of the tourist as he thinks of the destination. (2) } \\
\text { Atmosphere or mood: the mood that a precise destination creates in the tourist. It can come from factors that, } \\
\text { although concrete, can raise symbolic-emotional and experiential elements. (3) Distinctive or unique tourist } \\
\text { attractions: distinctive and/or unique elements that connote the destination and identify it in an univocal way" } \\
\text { (Scorrano et al., 2018: 340). }\end{array}$ & Qualitative \\
\hline 7. "Describe in your own words how the wildfires may impact California's wine industry" (Bauman et al., 2020: 2481). & Combined \\
\hline
\end{tabular}


One of the qualitative studies (Sottini et al., 2019) used Flickr platform to collect photos related to winescape concept and then analyzed the content. Bruwer and Alant (2009) used a questionnaire to capture both qualitative and quantitative data from winery visitors. Scherrer et al. (2009) interviewed wine industry representatives to explore their perceptions of Canary Island's wine tourism and DI. Regarding the quantitative data collection modes, a questionnaire survey was used as an instrument in 11 papers, while only one paper collected visual imagery from promotional material.

Most of the studies (nine papers) used five- and seven-point Likert scales. It is no surprise, while Likert scale is the most popular answer format for general DI studies too (Dolnicar and Grün, 2013). However, it is worth mentioning that Dolnicar and Grün (2013) compared the validity and performance of different answer format options in DI researches and found that the most dominant and common measurement approaches might not be performing the best. "The measure used most commonly in industry (the pick-any measure) produces misleading results because it allows respondents to evade responding. The most common measure used by academics (the multicategory Likert-type scale) does not perform well on the strict stability measure and takes longer to complete.

It is therefore recommended that researchers make increased use of the forced-choice full binary measure because it performs better than competing approaches in terms of stability and outperforms most other answer formats in terms of speed of completion. Note that the use of the forced-choice full binary answer format does not have any disadvantages with respect to data analysis" (Dolnicar and Grün, 2013: 10).

\section{Attributes used to measure destination image}

In quantitative studies of DI, researchers often use attributes to assess the perceptions of tourists. As explained in a section named Destination image measurement methods (data collection modes), attributes can be obtained from different sources, such as literature review, content analysis, free elicitation and so forth. In our sample of articles, literature review is the most common way to elaborate attribute-lists. Nine papers (75\%) use literature review. Bauman et al. (2020) and Bruwer et al. (2018) do not provide information about the exact source of attributes. Pratt and Sparks (2014) used literature review and qualitative research, but the details about latter is not discussed. Some studies (Bruwer et al., 2016, 2017; Bruwer and Gross, 2017; Bruwer and Joy, 2017; Bruwer and Lesschaeve, 2012) seem to be designing the scales or attribute-lists with consumer research as recommended by Echtner and Ritchie (1991) and Jenkins (1999).

"Currently there is no widely accepted scale that confirms the existence of the wine region attributes comprising the winescape" (Bruwer and Gross, 2017: 500). It is important to create a valid scale of attributes that could measure WTDI. It would have been useful to use the most accepted attribute-lists from general tourism DI studies but "the nature of the wine tourism product and experience requires that a research approach be developed that differs from the generic approaches used in mainstream TDI studies" (Bruwer et al., 2016: 183). Johan Bruwer and his co-authors have significantly contributed to researching winery visitors and their perceptions of wine regions to design winescape framework or, in other words, the most important characteristics of wine regions. But these winescape scales still need validation in other countries or wine regions (Bruwer and Gross, 2017).

\section{CONCLUSION}

Perceived image of a destination affects travelers' decision-making (Jenkins, 1999), and their satisfaction (Ajayi and Tichaawa, 2020), which is why marketers try to project images that are attractive for visitors (Haarhoff and De Klerk, 2019). For being competitive, wine regions need to project attractive and unique images as well as monitor the perceptions and impressions of wine tourists. WTDI studies initiated in 2001 by Williams (2001a), and since it has been gradually gaining attention. Travel DI researches typically have a destination as an object to study and respondents as subjects (Gallarza et al., 2002). WTDI papers consistently study wine regions as the object, but subject is varying. Winery visitors are the most common subject and lately some new samples emerged too. However, WTDI papers lack diversification into samples such as DMOs, travel representatives and residents. Nowadays, in the virtual era, reinforced by Covid-19, realizing the importance of virtual spaces, social media, platforms with user-generated content and blogs where wine tourists themselves can project the images of destination based on their own perceptions, is crucial. It also has a form of electronic word-of-mouth which is as fortified as never before. Future research may seek to explore the effect of the information available virtually on wine tourists' beliefs, and attitudes towards winescapes or wine regions.

In DI studies, the vast majority of authors use quantitative techniques (Echtner and Ritchie, 1991; Nghiêm-Phú, 2014; Pike, 2002), while in WTDI papers we discovered that the share of qualitative (43\%) and quantitative (48\%) methods are evenly distributed. $10 \%$ of papers utilize combined methods. Even though none of the techniques is overlooked, the studies do not operationalize the image measurement process involving both methods together as recommended by some of the most accepted DI studies (Echtner and Ritchie, 1991, 1993). In future authors may propose more research with both qualitative and quantitative techniques complementing each other.

Some WTDI papers use qualitative techniques such as consumer/wine tourist research and free elicitation for designing attribute-lists for further quantitative data collection. However, these scales are not validated yet and neither widely accepted in WTDI area. In future, we might see more studies focusing on validating these attribute-lists.

For now, the attribute-lists do not incorporate all the elements of WTDI. Qualitative studies which ask open-ended questions also fail to collect data about some of the components of WTDI, such as psychological holistic and unique characteristics. It is because these papers aim to design a scale and not exactly to explore the image of a specific destination. It would be necessary to consider in upcoming researches that "a focus on any component of destination image at the exclusion of the other components results in an in complete measurement" (Echtner and Ritchie, 1991: 46). 
It would also be worth to create a valid and all-inclusive attribute-list or scale with proper methods that could be used uniformly in WTDI research. As it is suggested by Dolnicar and Grün (2013), future research could start using forced-choice full binary measure instead of more popular Likert and pick-any answer formats, as it performs better.

Methodological limitation of our study is that the papers were collected and classified by only one researcher. There is a chance of biases as the researcher might have categorized the papers subjectively. In addition, the study has not overviewed the data analysis techniques and software used by each paper. This limitation encourages future research in these directions. Future research may also investigate projected images, as well as accordance between projected and perceived images, which would allow wine regions to plan and execute their promotional activities more effectively. Wine tourism destinations that wish to research their image can use the results of our study.

For studying the image, they should use the valid scales that future academic papers may propose and combine it with qualitative methods to learn deeply about the perceptions of the wine tourists they want to attract. It will guarantee a solid base for the successful promotional activities. To sum up, reviews of literature about WTDI will be necessary in future too to see the existing knowledge of the study field, its development, and characteristics. Reviews can indicate whether there are any methodological issues in the field and will facilitate its progress.

\section{REFERENCES}

Ahmed, Z.U. (1991). The influence of the components of a state's tourist image on product positioning strategy. Tourism Management, 12(4), 331-340. https://doi.org/10.1016/0261-5177(91)90045-U

Ajayi, O.O., \& Tichaawa, T.M. (2020). Visitors' characteristics and destination image: the case of Nigerian zoos. GeoJournal of Tourism and Geosites, 32(4), 1410-1417. https://doi.org/10.30892/gtg.3

Aleixandre, J.L., Aleixandre-Tudó, J.L., Bolaños-Pizarro, M., \& Aleixandre-Benavent, R. (2016). Viticulture and oenology scientific research: The Old World versus the New World wine-producing countries. International Journal of Information Management, 36(3), 389-396. https://doi.org/10.1016/j.ijinfomgt.2016.01.003

Andreu, L., Bigné, J.E., \& Cooper, C. (2000). Projected and perceived image of spain as a tourist destination for british travellers. Journal of Travel and Tourism Marketing, 9(4), 47-67. https://doi.org/10.1300/J073v09n04_03

Bauman, M.J., Yuan, J., \& Williams, H.A. (2020). Developing a measure for assessing tourists' empathy towards natural disasters in the context of wine tourism and the 2017 California wildfires. Current Issues in Tourism, 23(19), 2476-2491. https://doi.org/10.1080/13683500.2019.1681944

Boddy, C.R. (2016). Sample size for qualitative research. Qualitative Market Research, 19(4), 426-432. https://doi.org/10.1108/QMR-06-2016-0053

Bruwer, J., \& Alant, K. (2009). The hedonic nature of wine tourism consumption: an experiential view. International Journal of Wine Business Research, 21(3), 235-257. https://doi.org/10.1108/17511060910985962

Bruwer, J., \& Gross, M.J. (2017). A multilayered macro approach to conceptualizing the winescape construct for wine tourism. Tourism Analysis, 22(4), 497-509. https://doi.org/10.3727/108354217X15023805452059

Bruwer, J., Gross, M.J., \& Lee, H.C. (2016). Tourism destination image (TDI) perception within a regional winescape context. Tourism Analysis, 21(2), 173-187. https://doi.org/10.3727/108354216X14559233984692

Bruwer, J., \& Joy, A. (2017). Tourism destination image (TDI) perception of a Canadian regional winescape: a free-text macro approach. Tourism Recreation Research, 42(3), 367-379. https://doi.org/10.1080/02508281.2017.1318482

Bruwer, J., \& Lesschaeve, I. (2012). Wine Tourists’ Destination Region Brand Image Perception and Antecedents: Conceptualization of a Winescape Framework. Journal of Travel and Tourism Marketing, 29(7), 611-628. https://doi.org/10.1080/10548408.2012.719819

Bruwer, J., Pratt, M.A., Saliba, A., \& Hirche, M. (2017). Regional destination image perception of tourists within a winescape context. Current Issues in Tourism, 20(2), 157-177. https://doi.org/10.1080/13683500.2014.904846

Bruwer, J., Prayag, G., \& Disegna, M. (2018). Why wine tourists visit cellar doors: Segmenting motivation and destination image. International Journal of Tourism Research, 20(3), 355-366. https://doi.org/10.1002/jtr.2187

Bruwer, J., \& Rueger-Muck, E. (2019). Wine tourism and hedonic experience: A motivation-based experiential view. Tourism and Hospitality Research, 19(4), 488-502. https://doi.org/10.1177/1467358418781444

Chan, C.S., \& Zhang, Y. (2018). Matching projected image with perceived image for geotourism development: a qualitative-quantitative integration. Asian Geographer, 35(2), 143-160. https://doi.org/10.1080/10225706.2018.1527235

Chon, K.S. (1990). The role of destination image in tourism: a review and discussion. The Tourist Review, 45(2), 2-9. https://doi.org/10.1108/eb058040

Dávid, L., \& Bujdosó, Z. (2007). Perspectives of Wine tourism (A borturizmus perspektívái - In Hungarian) . Borászati Füzetek, 17(3), 28 -29.

Dolnicar, S., \& Grün, B. (2013). Validly Measuring Destination Image in Survey Studies. Journal of Travel Research, 52(1), 3-14. https://doi.org/10.1177/0047287512457267

Duffy, M.E. (2006). Resources for determining or evaluating sample size in quantitative research reports. Clin Nurse Spec., 20 (1), 9-12. https://doi.org/10.1097/00002800-200601000-00004

Echtner, C.M., \& Ritchie, J.R.B. (1991). The meaning and measurement of destination image. Journal of Tourism Studies, 14(1), 37-48. https://doi.org/10.1.1.89.3276

Echtner, C.M., \& Ritchie, J.R.B. (1993). The measurement of destination image: an empirical assessment. Journal of Travel Research, 31(4), 3-13. https://doi.org/10.1177/004728759303100402

Gallarza, M.G., Gil Saura, I., \& Calderón García, H. (2002). Destination image towards a conceptual framework. Annals of Tourism Research, 29(1), 56-78. https://doi.org/10.1016/S0160-7383(01)00031-7

Gómez, M., González-Díaz, B., \& Molina, A. (2015). Priority maps at wine tourism destinations: An empirical approach in five Spanish wine regions. Journal of Destination Marketing and Management, 4(4), 258-267. https://doi.org/10.1016/j.jdmm.2015.09.003

Gómez, M., Lopez, C., \& Molina, A. (2015). A model of tourism destination brand equity: The case of wine tourism destinations in Spain. Tourism Management, 51, 210-222. https://doi.org/10.1016/j.tourman.2015.05.019

Gómez, M., \& Molina, A. (2012). Wine Tourism in Spain: Denomination of Origin Effects on Brand Equity. International Journal of Tourism Research, 14(4), 353-368. https://doi.org/10.1002/jtr.868

Gómez, M., Molina, A., \& Esteban, Á. (2013). What are the main factors attracting visitors to wineries? A PLS multi-group comparison. Quality and Quantity, 47(5), 2637-2657. https://doi.org/10.1007/s11135-012-9676-5 
Gómez, M., Pratt, M.A., \& Molina, A. (2019). Wine tourism research: a systematic review of 20 vintages from 1995 to 2014 . Current Issues in Tourism, 22(18), 2211-2249. Routledge. https://doi.org/10.1080/13683500.2018.1441267

Grant, M.J., \& Booth, A. (2009). A typology of reviews: An analysis of 14 review types and associated methodologies. In Health Information and Libraries Journal, 26(2), 91-108. https://doi.org/10.1111/j.1471-1842.2009.00848.x

Haarhoff, R., \& De Klerk, B. (2019). Destination South Africa: Analysis of destination awareness and image by international visitors. GeoJournal of Tourism and Geosites, 24(1), 201-211. https://doi.org/10.30892/gtg.2

Hall, C.M., Sharples, L., Cambourne, B., \& Macionis, N. (2000). Wine Tourism Around the World Development, management and markets (C.M. Hall, ed).

Ilieş, A., Ilieş, D.C., Josan, I., Grama, V., \& Gozner, M. (2008). Romanian rural tourism between authentic/traditional and modern/contemporary. The case of Crişana and Maramureş areas. GeoJournal of Tourism and Geosites Year I, 2(2), 140-148.

Israel, G.D. (1992). Determining Sample Size [Fact sheet PEOD-6]. Florida Cooperative Extension Service / Institute of Food and Agricultural Sciences / University of Florida.

Jacso, P. (2005). As we may search-Comparison of major features of the Web of Science, Scopus, and Google Scholar citation-based and citation-enhanced databases. Current Science, 89(9), 1537-1547.

Jenkins, O.H. (1999). Understanding and Measuring Tourist Destination Images. https://doi.org/10.1002/(SICI)1522-1970(199901/02) $1: 1<1::$ AID-JTR143>3.0.CO;2-L

Johnson, R., \& Bruwer, J. (2007). Regional brand image and perceived wine quality: The consumer perspective. International Journal of Wine Business Research, 19(4), 276-297. https://doi.org/10.1108/17511060710837427

Kwek, A., \& Lee, Y.S. (2008). Intra-cultural variance of chinese tourists in destination image project: Case of Queensland, Australia. Journal of Hospitality and Leisure Marketing, 16(1-2), 105-135. https://doi.org/10.1080/10507050802096984

Madeira, A., Correia, A., \& Filipe, J.A. (2019). Modelling wine tourism experiences. Anatolia, 30(4), 513-529. https://doi.org/ $10.1080 / 13032917.2019 .1642922$

Malterud, K., Siersma, V.D., \& Guassora, A.D. (2016). Sample Size in Qualitative Interview Studies: Guided by Information Power. Qualitative Health Research, 26(13), 1753-1760. https://doi.org/10.1177/1049732315617444

Nemethy, S., Lagerqvist, B., Walas, B., Dinya, L., \& Bujdoso, Z. (2016). Oenotourism and conservation: a holistic approach to special interest tourism from a cultural heritage perspective - the Azienda Agricola Model. Ecocycles, 2(1). https://doi.org/10.19040/ecocycles.v2i1.39

Nghiêm-Phú, B. (2014). A review of destination image studies from 2008 to 2012. European Journal of Tourism Research, 8, 35-65.

Noruzi, A. (2005). Google Scholar: The new generation of citation indexes. Libri, 55(4), 170-180). https://doi.org/10.1515/LIBR.2005.170

Pike, S. (2002). Destination image analysis-a review of 142 papers from 1973 to 2000. Tourism Management, 23, 541-549. https://doi.org/10.1016/S0261-5177(02)00005-5

Pratt, M.A., \& Sparks, B. (2014). Predicting Wine Tourism Intention: Destination Image and Self-congruity. Journal of Travel and Tourism Marketing, 31(4), 443-460. https://doi.org/10.1080/10548408.2014.883953

Quintal, V.A., Thomas, B., \& Phau, I. (2015). Incorporating the winescape into the theory of planned behaviour: Examining "new world" wineries. Tourism Management, 46, 596-609. https://doi.org/10.1016/j.tourman.2014.08.013

Sampaio, A. (2012). Wine tourism and visitors' perceptions: A structural equation modelling approach. Tourism Economics, 18(3), 533553. https://doi.org/10.5367/te.2012.0132

Scherrer, P., Alonso, A., \& Sheridan, L. (2009). Expanding the destination image: Wine tourism in the Canary Islands. In International Journal of Tourism Research, 11(5), 451-463. https://doi.org/10.1002/jtr.713

Scorrano, P., Fait, M., Iaia, L., \& Rosato, P. (2018). The image attributes of a destination: an analysis of the wine tourists' perception. EuroMed Journal of Business, 13(3), 335-350. https://doi.org/10.1108/EMJB-11-2017-0045

Sottini, V.A., Barbierato, E., Bernetti, I., Capecchi, I., Fabbrizzi, S., \& Menghini, S. (2019). Winescape perception and big data analysis: An assessment through social media photographs in the Chianti Classico region. Wine Economics and Policy, 8(2), $127-140$. https://doi.org/10.1016/j.wep.2019.07.001

Stepchenkova, S., \& Mills, J.E. (2010). Destination image: A meta-analysis of 2000-2007 research. Journal of Hospitality Marketing and Management, 19(6), 575-609. https://doi.org/10.1080/19368623.2010.493071

Tasci, A.D.A., Gartner, W.C., \& Tamer Cavusgil, S. (2007). Conceptualization and operationalization of destination image. Journal of Hospitality and Tourism Research, 31(2), 194-223. https://doi.org/10.1177/1096348006297290

Weller, S.C., Vickers, B., Russell Bernard, H., Blackburn, A.M., Borgatti, S., Gravlee, C.C., \& Johnson, J.C. (2018). Open-ended interview questions and saturation. PLoS ONE, 13(6). https://doi.org/10.1371/journal.pone.0198606

Williams, P. (2001a). The Evolving Images of Wine Tourism Destinations. Tourism Recreation Research, 26(2), 3-10. https://doi.org/10.1080/02508281.2001.11081338

Williams, P. (2001b). Positioning wine tourism destinations: an image analysis. International Journal of Wine Marketing, 13(3), 42-58. https://doi.org/10.1108/eb008726

Wu, G., \& Liang, L. (2020). Examining the effect of potential tourists' wine product involvement on wine tourism destination image and travel intention. Current Issues in Tourism, (1-15). https://doi.org/10.1080/13683500.2020.1828310

*** SCImago. (n.d.). SJR - SCImago Journal \& Country Rank [Portal]. Retrieved on 10.01.2021. from http://www.scimagojr.com

Article history: Received: 19.02.2020 Revised: 12.05.2021 Accepted: 29.06.2021 Available online: 21.07.2021 